DOI https://doi.org/10.18551/rjoas.2017-03.04

\title{
THE ESSENCE OF LABOUR AS A FACTOR DISTORTING THE ASSESSMENT OF INDIVIDUAL COMPETITIVENESS IN THE LABOUR MARKET
}

\author{
Sabetova T.V., Candidate of Economics, Associate Professor \\ Voronezh State Agrarian University named after Peter the Great, Voronezh, Russia \\ E-mail: tsabetova@mail.ru
}

\begin{abstract}
The article concerns the problem of distortion of quantitative assessment of an individual's or a group's competitiveness within the labour market. The author defines a number of factors affecting the competitiveness assessment, dividing them into direct and indirect factors. The article thoroughly discusses only the one of the said factors - namely, specific characteristics of the labour service. Among such characteristics the author pays special attention to intangibility, heterogeneity, inseparability of employer and employee, impossibility of storing. Intangibility and lack of wearibility of labour and professional competencies cause difficulties in competency cost (or knowledge cost) calculation and grounding. This may result in inadequate wages. Impossibility to store labour brings about the labour market sensitivity to economic fluctuations during the business cycle. Heterogeneity of the labour service, in the author's opinion, gives both positive and negative results for the labour market and economy in general. Without this feature no differentiation of labour would be possible as well as professional growth, or professional mobility. On the other hand, it causes uncertainty in planning, recruiting, training, and labour stimulation. Inseparability of employer and employee makes active interaction between them absolutely necessary for good results of work relations. So, the author states that any model of quantitative assessment of individual or group competitiveness within the labour market should bear some adjustments taking into account the factors distorting competition situation in this market and competitiveness evaluation.
\end{abstract}

\section{KEY WORDS}

Labour market, individual competitiveness assessment, distorting factors, service market.

Unbiased, complex, and precise quantitative assessment of an individual's or a group's competitiveness within the labour market is impeded by a number of factors varying in the degree and direction of such influence. Some of them limit the availability of quantitative information concerning the objects and processes, others alter the dependences and connections between them, still others add uncertainty to the market laws.

Not all of these factors negatively affect the labour market itself, as well as the work life of individuals. However, positive influence of a part of them does not cancel the fact of the parameter distortion.

\section{PROBLEM STATEMENT}

Despite considerable diversity among the said factors, and sometimes complete absence of any connection between them, we think it possible to mark the most influential among them, based on the degree of their effect on the possibility of exact assessment of individuals' competitiveness, and to classify them into groups based on the object of their influence. We outlined two classification groups of the factors distorting the quantitative assessment of individual competitiveness within the labour market (fig.1): 


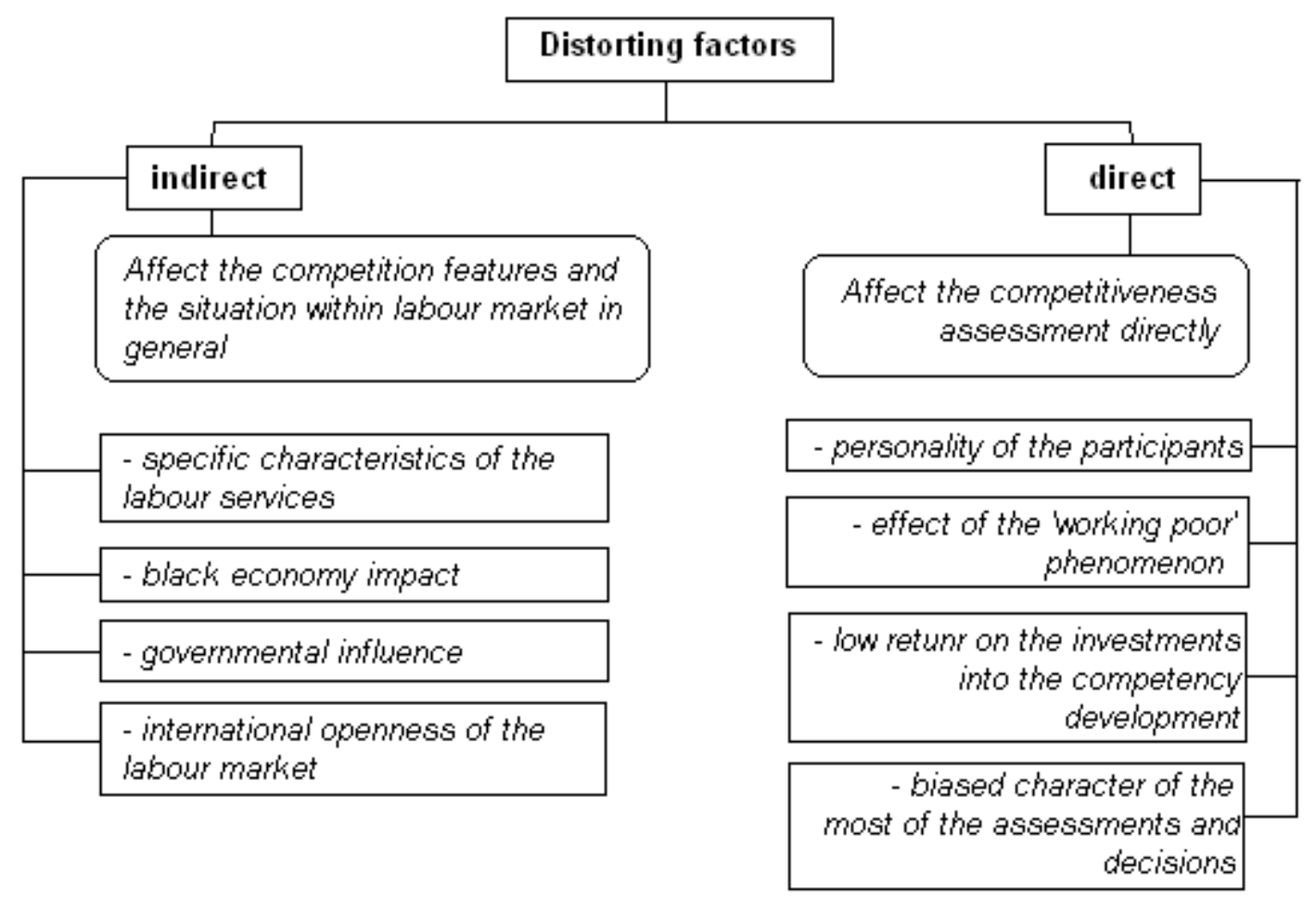

Figure 1 - Classification of the factors distorting the quantitative assessments of individual competitiveness within the labour market

1. The factors actually affecting the competition within the labour market, its rules and processes, connections among the rivalry forces, etc. Distorting the competition situation, such factors affect the manifestation of the individual competitiveness and its assessment. It should be noted, that they equally affect the competitiveness of any labour market participants, such as employees, applicants, groups, employers, entrepreneurs, etc. The key factors of this group, in our opinion, include:

i) specific characteristics of the labour service itself;

ii) the influence of the black economy;

iii) governmental influence upon the labour market which can be observed in two very different roles of the state: one of a lawmaker and the other of a huge and influential employer;

iv) labour market openness and the impact of migration processes.

2. The factors directly distorting competitiveness assessment, its indicators, competitors' objectives, observer's opinions (for instance, limiting his access to the unbiased information). Here we concern the phenomena operating only in regard of the individual labour market participants and their competitiveness. We include the following in this group:

i) personal features of the individuals such as their values, needs and ideas; we suggest to call this phenomenon 'subjectifying factor';

ii) existence of a great number of the so-called working poor in the labour market; their distorting effect consists of competition for actually disadvantageous jobs;

iii) low return on the personal investments into development of professional competencies, in particular, education;

iv) biased character of any assessments of an individual concerning his prospects within the labour market, psychological impossibility of absolutely impersonal and correct assessment (even if all required information is available).

In this article we thoroughly discuss only the first of the factors mentioned above, which is the specific characteristics of the labour service, as in our opinion its distorting influence upon the competitiveness of the labour market participants is the most substantial. 


\section{ANALYSIS AND DISCUSSION}

The essence of the labour service as goods to be exchanged within the labour market makes considerable impact on the whole situation in this resource market. Product rivalry is much simpler than rivalry among services. The reason is that there is an additional rivalry level in the service markets compared to product markets (table 1).

Table 1 - Rivalry levels in the service and product markets

\begin{tabular}{|c|c|c|}
\hline Level & Product & Service \\
\hline Topmost (need) & \multicolumn{2}{|c|}{$\begin{array}{l}\text { Decision concerning to satisfaction of which need of an individual or a household his/its } \\
\text { budget should be used for }\end{array}$} \\
\hline Second (class) & Commodity group / type & Service type \\
\hline Third A (subclass) & $\begin{array}{l}\text { Specific product description / } \\
\text { variation }\end{array}$ & Specific service description \\
\hline $\begin{array}{l}\text { Third B } \\
\text { (manufacturer) }\end{array}$ & Manufacturing company & Providing company \\
\hline $\begin{array}{l}\text { Fourth } \\
\text { (intracompany) }\end{array}$ & $\mathrm{X}$ & $\begin{array}{l}\text { Certain person or group performing the service act in } \\
\text { question }\end{array}$ \\
\hline
\end{tabular}

The presence of an 'extra' rivalry level both complicates the customer's choice, and makes the competitiveness management for the company and the goods more difficult. In case of material product it is normally enough just to streamline the technology and establish quality control so that every unit of a certain product type/model leave the plant with absolutely unified parameters for competitiveness. The only possible exception here is waste, but the quality control of the output of the plant and at the retailer help to eliminate the possibility of it reaching the clients' scope. At a result the client does not even think of choosing among several copies of the same product model stocked at a warehouse or store.

But everything is different in the service sector. No unification or control helps achieving exactly the same results and the degree of the client's satisfaction in any service subsector. The amount of manual work, features of the applied equipment, effort of management aiming at the service unification do matter, but cannot solve the problem completely.

As for the labour market, which we understand as one particular type of service markets, all the typical features of the service markets are observed here (table 2). However, they are often complicated by the specific characteristics of the essence of the labour service viewed as goods.

Table 2 - Specific characteristics of the labour service viewed as goods

\begin{tabular}{|l|l|}
\hline \multicolumn{1}{|c|}{ Service feature [7] } & \multicolumn{1}{c|}{ Its manifestation in relation to labour service } \\
\hline $\begin{array}{l}\text { Incorporeity, intangibility. Even when a service } \\
\text { leads to creation of physical result (a book, } \\
\text { hairstyle, etc.), the process remains primary }\end{array}$ & $\begin{array}{l}\text { Clearly manifested. The labour remains primary object of } \\
\text { attention whether its results are physical or intangible }\end{array}$ \\
\hline Cannot be stored or set up reserves & $\begin{array}{l}\text { Clearly manifested. It complicates human resource } \\
\text { provision of a company's operation in management }\end{array}$ \\
\hline $\begin{array}{l}\text { Heterogeneity. The same service performance } \\
\text { depends on the executor, conditions, and in some } \\
\text { cases - on the customer }\end{array}$ & $\begin{array}{l}\text { Clearly manifested. When different people take the same } \\
\text { position in a company, it may lead to very different results. } \\
\text { Sometimes even the same person performs the same work } \\
\text { differently under different conditions and at various periods } \\
\text { of time }\end{array}$ \\
\hline $\begin{array}{l}\text { Inseparability of production and consumption. The } \\
\text { client usually is present (transport, healthcare, } \\
\text { beauty industry, etc.), and sometimes actively } \\
\text { participates (education, tourism) in service } \\
\text { performance }\end{array}$ & $\begin{array}{l}\text { Clearly manifested. Labour effort cannot be put into no } \\
\text { particular object. Often the consumer of the hired labour } \\
\text { has to create certain conditions granting the employees the } \\
\text { opportunity for efficient work performance }\end{array}$ \\
\hline \multicolumn{2}{|l}{}
\end{tabular}

Each of the particulars listed in the table 2 complicates the labour market situation and participants' activities there (both employers and employees). 
The first feature of services raises the situation when the seller of services cannot demonstrate the service characteristics and quality to clients, thus arguing their expenditures and price. In the labour market this problem is even more obvious. The seller of labour, which is an individual, or employee, has already spent considerable resources (both his own effort and money, which can be direct expenses as well as the benefit sacrificed) to acquire and develop his competencies up to their variety and level, required in accordance with the desired position. The individual continues to spend his strength and abilities for his work, expecting remuneration for both current and past investments and benefit sacrificed. However, the essence of the both organizational and individual knowledge [11] as a resource for production is such, as it being applied to some economic activity, cannot be spent and transfer its cost to the manufactured goods, and depreciation is not applicable here as well [10]. On the contrary, it is quite typical that knowledge grows and improves due to its application: the individual gains additional experience and develops his competencies.

As a result we observe an interesting phenomenon in labour remuneration.

The price for any good is formed under the impact of certain factors (fig.2):

i) the lower limitation of the price is defined by the company's expenditures for production and distribution (total cost) and its expectation concerning profitability;

ii) governmental intervention, both direct and indirect, can set up both lower and upper limits of the price range;

iii) the upper price limit is defined by competitors' influence and consumers' effective demand.

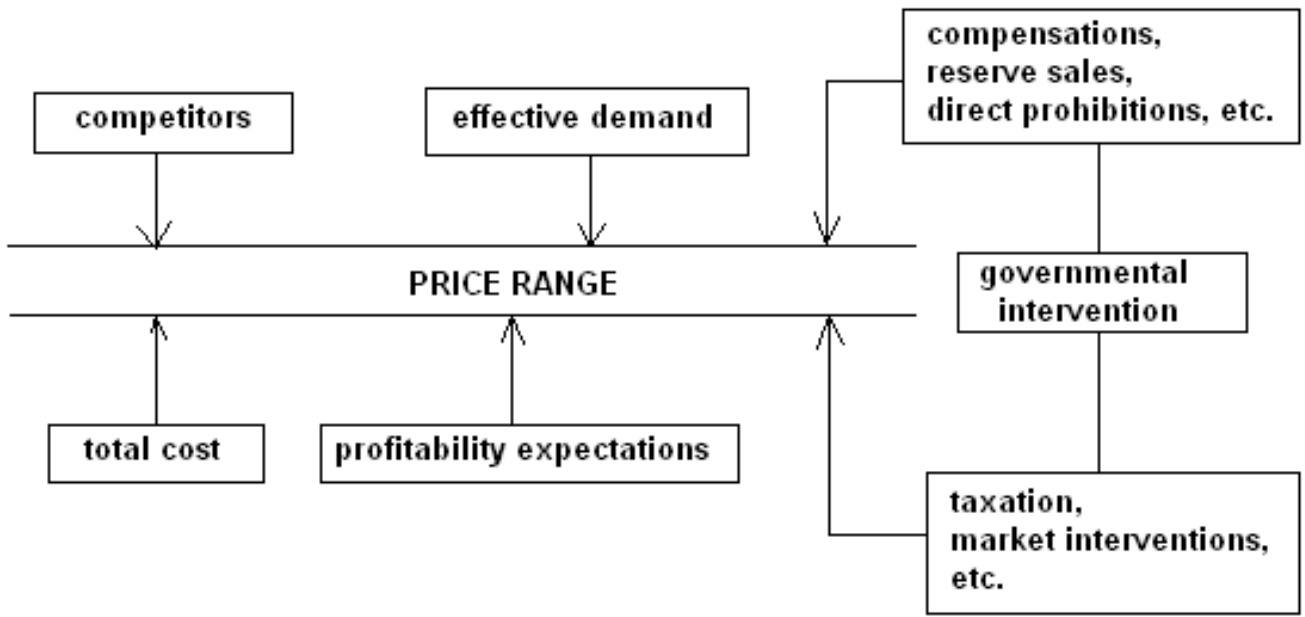

Figure 2 - Factor affecting the goods price range

Notionally, the same situation is expected within the labour market:

i) governmental intervention, though it usually sets the minimum wage, also may limit the highest possible salary as well as its structure and differentiation;

ii) the upper limit of wages may be interpreted as the added value created by the paid labour, but in most cases of hired labour the total of the added value cannot be given to the employee as the salary, part of it remains within the company to form its profit, return on investment, and sometimes the reserve for fair, or unfair redistribution;

iii) the lower limit cannot be set by the amounts necessary for the employee's physical survival and simple reproduction, as it should also cover (and accordingly stimulate other potential performers) the past cost of competency development up to the level required for the activity in question. 


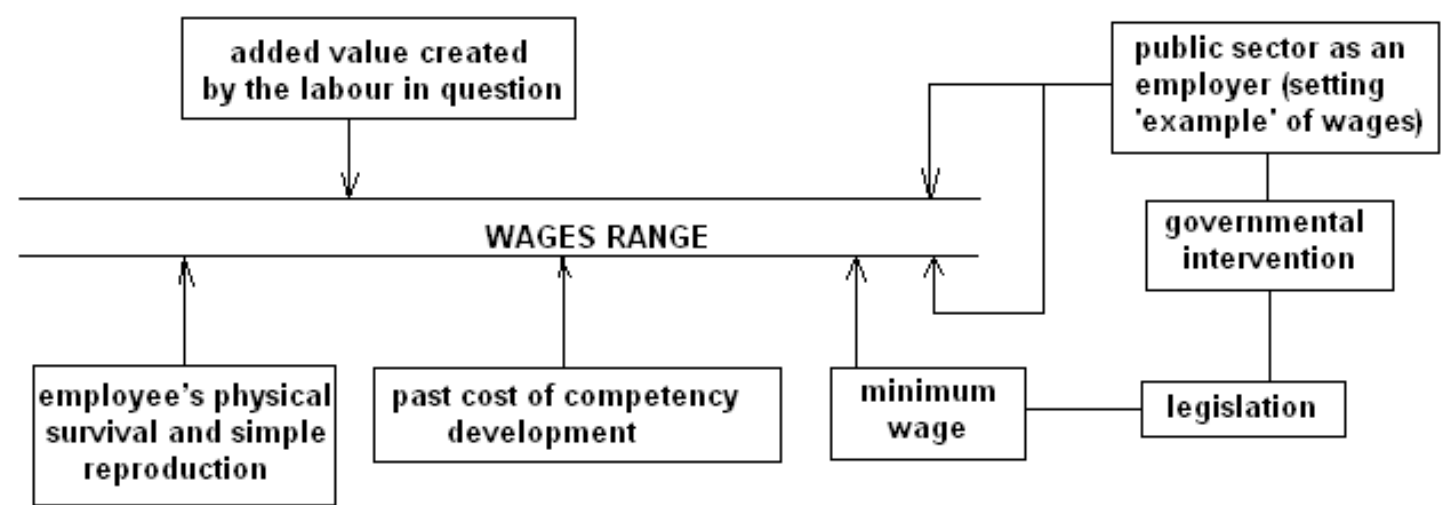

Figure 3 - Factor affecting the wage range in the labour market

However, in reality, firstly, it might be quite difficult or even impossible to assess the monetary value of the effort put in achieving the competency level possessed by a certain employee. Secondly, it is not completely clear, what part of such effort should be compensated during a particular part of individual's work life, as the competencies cannot be physically spent. The situation is even further complicated by the idea, that the individual may need various sets of competencies in the course of his life (for instance, in different positions or companies, etc.), and it is impossible to predict the time limits of a given competency use due to considerable duration of the work life (it is usually 30 to 44 years, without taking into account the possibility of continued employment after reaching retirement age). As a result we can observe the facts of considerably higher wages for a simple job compared to complex one; dangerous and harmful compared to ordinary; highly skilled compared to menial one.

Impossibility to store labour, as well as any other type of services, brings about a lot of difficulties in the labour market, making it very sensitive to the demand fluctuations in the markets of the ultimate goods manufactured by the labour in question. However, employees under contract with employers have certain legal guarantees, despite reduction of the demand for their labour. Sometimes the employers are also interested in keeping their staff during downswing, especially if they need special or rare skills, obtained through long training of experience, for effective job performance. In any case, the distortion of competitiveness here takes place, as the conditions created for a valuable employee still might worsen under crisis.

Still, part of staff is fired at the decline of the business cycle, but this happens later than for other resources. On the other hand, at the growth stage new hiring is going on slower than it is required due to employers' wariness and lack of the necessary specialists in the market, ad part of them after being fired moved to different segments of the market - other professions or spheres, and remain there, or lost the required qualification.

So, when the facilities for services exceed the demand, it causes business profitability reduction or price drop. In the labour market such excess is also compensated by the wages as labour price, but it cannot decline endlessly, below the sustenance level for the employee. This fact greatly justifies active governmental intervention to the labour market, as well as the activities of various human rights organizations and trade unions, protecting the most vulnerable market participants, employees. Meanwhile, actually the most vulnerable labour market participants are the self-employed, acting in accordance to the paid service contracts. This leads us to the idea of necessity of additional regulation of interaction between such individuals and their clients. However, though the regulation of employer - employee relations greatly tightened during the last century (or, should we state, during the period of existence of International Labour Organization), the situation between the self-employed and their clients has not changed a lot since the Middle Age.

Heterogeneity of the labour service, in our opinion, is not synonymous to labour market heterogeneity, which should be understood as it being naturally divided into various 
segments - geographic, professional, sectorial, etc. Whereas here we allude not to the fact of many different segments with various conditions, but to the wide variety of labour activities themselves, even when we discuss similar or same positions in the similar or same companies, performed by similar individuals in terms of their description, competencies and functions. As each person in the world is unique, his/her work performance and results differ from those of others. Moreover, even the performance of the same person at the same position may vary in time. This happens due to the difference of abilities, conditions, professional and social competencies, current psychological state, long-term values and needs, activity motivation and stimulation.

Such heterogeneity gives both positive and negative results within the labour market. The former undoubtedly include:

i) however different the employers' requirements for the vacancy applicant may be, still it is very probable that somewhere in the market there is the 'ideal' candidate for each position in the world, so the only limitation for his recruitment is time restriction and shortage of relevant information;

ii) variations of the same individual's performance may be sporadic, but it is possible to control and manage them, sooner or later achieving the desired results of reducing deviations; education, experience and professional growth, in essence, are controlled and directed variations;

iii) the smallest differences in the individual abilities and skills may result in very minute and sometimes informal differentiation of labour within a work team, leading to sufficient positive economic and psychological results.

However, we cannot deny a number of negative consequences of the observed heterogeneity of the labour service, such as:

i) unpredictable work results and complications of their assessment, which may lead to incorrect planning or deficiencies of control procedures and of labour remuneration system;

ii) to a certain degree one may argue, that employer selects his staff at random, as the results of screening, training, or probation cannot guarantee that the parameters observed should remain during the whole period of the individual's employment;

iii) decline of the efficiency of any measures for staff training, impossibility of unobstructed spread of successful experience in this field from one business unit or even person to others;

iv) need for permanent effort, potentially associated with considerable expenses, for staff motivation and stimulation for good performance and achievement of the business objectives.

Inseparability of production and consumption makes necessary the direct contact between the market participant providing the service, and the participant consuming it (client). The service markets can be classified based on the degree of participation of the client in the service provision: from the services nearly separated from the client (for instance, some customer services such and dry-cleaning), to those where the client has to be physically present during the whole period of the service performance (transport, healthcare), or even has to play an active part in the service (education) [8]. The labour market should be considered the example of the latter type of service market, where active interaction of the seller (employee) and the buyer (employer) is required.

The resulting peculiarities of such interaction considerably complicate the quantitative assessment of an individual competitiveness. It is impossible to deny, that the obtained individual's performance, though requiring his own competencies, motives, and effort, are greatly affected by a number of factors depending on and managed by the employer:

i) labour conditions;

ii) workplace layout, availability of required information and means for its processing and storing;

iii) coordination of operations within a work team (this term here means any group of people interrelated in terms of some work, result, or process, aiming at the same measurable target);

iv) applied labour remuneration system; 
v) staff morale;

vi) the employee's functions, set in job description as well as occasional directions.

At the same time it should be too primitive to suppose, that within the same company all the employees are in equal conditions. Consequently, it is incorrect to assess an individual's competitiveness only by comparison with his/her colleagues, without taking into consideration the influence of the employer's (labour service consumer) actions on the performance of the person in question. So, though we recognize competitiveness manifestation within the in-business labour market and the possibility of its assessment by means of certain quantitate indicators, we insist on the necessity of adjustments of such assessment taking into account the employer's impact upon the given employee's performance.

\section{CONCLUSION}

The specific characteristics of the labour service as a particular market exchange object give the basis to our opinion about similarity between the service market thoroughly studied by marketing [2, 5, 6], and the labour market as its special case. Thus, T.D.Burmenko and others [1], after analysing foreign and Russian literature, generalized various opinions and defined the features of the service market which, from our point of view, can be directly applied to the labour market:

i) highly responsive processes associated with impossibility to store any services including labour;

ii) pronounced segmentation of the demand, labour market heterogeneity, which does not just exists but increases together with economic and technical development;

iii) high differentiation which is more pronounced in the labour market than in any other service market, as employers in the modern knowledge economy sometimes need unique specialist, even the only one in the country or world;

iv) geographic segmentation of the labour market may be more or less important depending on the mobility of the human resources, but in Russia this segmentation and segregation is traditionally high because of the cultural influence and infrastructure poor development;

v) the lesser market participants in the case of labour market are individuals, or labour service providers;

vi) great adaptation abilities of individuals, as each of them during his work life grows and improves, though sometimes degrades, but anyway his working abilities change.

In the view of the foregoing, the essence of labour and its similarity to services, we suppose it to be the key factor complicating the unbiased quantitative assessment of individual competitiveness in the labour market. However, the influence of the other factors listed in the beginning of the article is also considerable. Thus, we have to stress out, that any suggested model of individual or group competitiveness assessment model should hold certain adjustments to take into consideration the factors distorting and complicating the direct competitiveness assessment.

\section{REFERENCES}

1. Burmenko T.D. Sfera uslug v sovremennom obshchestve: Ekonomika, menedzhment, marketing. Kurs lekcij / T.D.Burmenko, N.N.Danilenko, T.A.Turenko. - Elektronnyj resurs, rezhim dostupa: http://freebooks.site/economics-uchebnik/tema-ryinok-uslug.

2. Vengerovskij E.L. K voprosu ob osobennostyah konkurentnyh otnoshenij na rynke bankovskih uslug /I Materialy III Mezhdunarodnogo nauchnogo kongressa "Predprinimatel'stvo i biznes $v$ usloviyah ekonomicheskoj nestabil'nosti". Finansovyj universitet pri Pravitel'stve RF. 2015. S. 261-263.

3. ZHurkina T.A. Analiz proizvoditel'nosti truda, faktory ee rosta / T.A.ZHurkina, T.N.Lihacheva // Ekonomika i predprinimatel'stvo. 2015. № 10-2 (63-2). S. 1012-1014.

4. ZHurkina T.A. Soderzhanie ponyatiya «proizvodstvennyj potencial» // Al'manah 
sovremennoj nauki i obrazovaniya. 2011. № 2. S. 152-154.

5. Kurbanov A.H. Analiz nekotoryh osobennostej razvitiya rynka logisticheskih uslug $v$ Rossii / Aktual'nye voprosy razvitiya sovremennogo obshchestva: sbornik statej 4-oj Mezhdunarodnoj nauchno-prakticheskoj konferencii: v 4-h tomah. 2014. S. 448-452

6. Maksudova A.D. Osobennosti primeneniya marketingovyh tekhnologij na rynke uslug svyazi // Regional'nye problemy preobrazovaniya ekonomiki. 2011. № 1. S. 434-440.

7. Marketing $\mathrm{v}$ otraslyah i sferah deyatel'nosti: uchebnoe posobie / pod red. N.A.Nagapet'yanca. M.: Vuzovskij uchebnik, 2007. 272 s.

8. Morgulec' O.B. Menedzhment v sfere uslug: Uchebnoe posobie / O.B.Morgulec'. - Kiev, CUL, 2012. $384 \mathrm{~s}$.

9. SHevcova N.M. Rol' vysshih uchebnyh zavedenij $v$ innovacionnom razvitii APK Belgorodskoj oblasti // Organizacionno-ekonomicheskij mekhanizm innovacionnogo razvitiya agropromyshlennogo kompleksa. Voronezh, 2014. S. 247-251.

10. Dalkir K. Knowledge Management in Theory and Practice. - Massachusetts Institute of Technology, Cambridge, Massachusetts, 2011.

11. Davenport, T., Prusak, L. Working knowledge. - Boston, Harvard Business School Press, 1998.

12. Osobennosti gosudarstvennogo regulirovaniya sel'skohozyajstvennogo proizvodstva pri vstuplenii Rossii v VTO / Zolotareva E.L., Veklenko V.I., SHamina I.L. // Vestnik Kurskoj gosudarstvennoj sel'skohozyajstvennoj akademii. 2013. №9. S. 37-39.

13. Proektirovanie optimal'nogo razmeshcheniya sel'skohozyajstvennogo proizvodstva $v$ regione / Novikova T.V., SHatohin M.V. I/ Vestnik Kurskoj gosudarstvennoj sel'skohozyajstvennoj akademii. 2010. T. 2. №2. S. 33-35.

14. Ekonomicheskij process kak osnova formirovaniya ekonomicheskoj sistemy / Miheev S.S. // Problemy regional'noj ekonomiki. 2010. №11. S. 3-10.

15. Prognozirovanie parametrov proizvodstvennyh zatrat i ob"emov proizvodstva produkcii sel'skogo hozyajstva / Zolotareva E.L., Zolotarev A.A., Babenko R.V., Sudzhenko I.A. // Vestnik Kurskoj gosudarstvennoj sel'skohozyajstvennoj akademii. 2011. №6. S.25-27.

16. Rol' gosudarstvennogo regulirovaniya vosproizvodstvennyh processov zemel'nyh resursov / Kovynev L.B. // Vestnik Kurskoj gosudarstvennoj sel'skohozyajstvennoj akademii. 2013. №1. S. 19-21.

17. Neobhodimost' i osnovnye napravleniya sovershenstvovaniya cenovogo mekhanizma $v$ sfere APK / Zolotareva E.L., Pyaseckij I.A. // Vestnik Kurskoj gosudarstvennoj sel'skohozyajstvennoj akademii. 2012. №4. S. 2-4.

18. Tendencii urovnya zanyatosti i bezraboticy $v$ sel'skom hozyajstve / Parxomchuk M.A., Doroshenko D.I. // Agrarnaya nauka. 2009. №8. S. 6-8.

19. Nauchnoe obespechenie innovacionnogo razvitiya sel'skogo hozyajstva Kurskoj oblasti / Semykin V.A. // Vestnik Kurskoj gosudarstvennoj sel'skohozyajstvennoj akademii. 2008. T. 1. №1. S. 3-7.

20. Usloviya i faktory razvitiya vosproizvodstvennyh processov / Zolotareva E.L., Babenko R.V., Arhipov K.V. // Vestnik Kurskoj gosudarstvennoj sel'skohozyajstvennoj akademii. 2011. T. 5. №5. S. 14-16.

21. Uroven' zanyatosti i bezrabotica v sel'skom hozyajstve / Parhomchuk M.A., Doroshenko D.I. // Vestnik Kurskoj gosudarstvennoj sel'skohozyajstvennoj akademii. 2009. T. 3. №3. S. $13-17$. 